Check for updates

Cite this: RSC Adv., 2018, 8, 31603

Received 15th August 2018

Accepted 5th September 2018

DOI: $10.1039 / \mathrm{c} 8 \mathrm{ra06826g}$

rsc.li/rsc-advances

\title{
Acid-promoted iron-catalysed dehydrogenative [4 +2 ] cycloaddition for the synthesis of quinolines under air $\dagger$
}

\author{
Jinfei Yang, (D)* Xiao Meng, Kai Lu, Zhihao Lu, Minliang Huang, Chengniu Wang \\ and Fei Sun*
}

\begin{abstract}
An acid-promoted iron-catalysed dehydrogenative [4 +2] cycloaddition reaction was developed for the synthesis of quinolines using air as a terminal oxidant. Acetic acid was the best cocatalyst for the cycloaddition of $\mathrm{N}$-alkyl anilines with alkenes or alkynes under air. Various quinoline derivatives were obtained in satisfactory-to-excellent yields, and no other byproducts besides water were produced in the reaction. The zebrafish model has become an important vertebrate model for evaluating drug effects. We tested the activity of $3 n$ in zebrafish. The test results showed that $1 \mu \mathrm{g} \mathrm{mL}^{-1} 3 \mathrm{n}$ treatments resulted in morphological malformation, and $0.01-0.1 \mu \mathrm{g} \mathrm{mL}^{-1} 3 \mathrm{n}$ treatments led to potent angiogenic defects in zebrafish embryos. The results of this study will be of great significance for promoting drug research in cardiovascular and cerebrovascular diseases.
\end{abstract}

The construction of quinoline motifs has received intensive attention owing to their potential application in photovoltaic devices $^{1}$ and pharmaceuticals, ${ }^{2}$ such as anticancer, antiviral, antifungal, antiplatelet aggregation, antimalarial, antibacterial, antileishmanial and anti-inflammatory medicine. ${ }^{3}$ Because of their importance, many methods have been reported for the synthesis of quinolines. ${ }^{4}$ Among them, the most attractive strategy for the synthesis of these compounds is the dehydrogenative $[4+2]$ cycloaddition through transition-metal catalysis and Lewis/ Bronsted acid catalysis. In its most general and classical form, dehydrogenative $[4+2]$ cycloaddition catalysed by transition metals such as $\mathrm{Fe},{ }^{5} \mathrm{Cu},{ }^{6} \mathrm{Pd},{ }^{7}$ and others, ${ }^{8}$ has been used as a potent tool for the synthesis of quinolone derivatives (Scheme 1a). However, these methods require the presence of excess peroxides, chloranil, potassium persulfate or other oxidants to promote the cycloaddition reaction and to obtain good product yields. Furthermore, in these processes, the formation of stoichiometric amounts of acid or tetrachlorohydroquinone waste as byproducts is a substantial problem that has limited their use. To overcome these drawbacks, several methods that utilise oxygen as a terminal oxidant have been reported. ${ }^{9}$ However, in many cases, the industrial use of these methods is problematic owing to operational difficulty. Therefore, the development of more efficient and economical synthetic methods is still necessary. Undoubtedly, the use of air as a terminal oxidant is the best choice. In addition, in the field of transition-metal catalysis, iron is one of the most

Medical School, Institute of Reproductive Medicine, Nantong University, Nantong 226019, China.E-mail: jfyang@ntu.edu.cn; sunfei@ntu.edu.cn

$\dagger$ Electronic supplementary information (ESI) available. See DOI: $10.1039 / \mathrm{c} 8 \mathrm{ra06826g}$ commonly used base metals and has been widely applied in various coupling reactions. ${ }^{10}$ Therefore, it is desirable to develop an iron-catalysed dehydrogenative cycloaddition for the synthesis of quinoline under air.

Herein, we report the first acid-promoted iron-catalysed dehydrogenative [4+2] cycloaddition of $N$-alkyl anilines with alkenes or alkynes using air as a terminal oxidant (Scheme 1b). Iron-catalysed cycloaddition reaction for the synthesis of quinolines under air has always been a challenge because of metal deactivation after the end of the catalytic cycle. We commenced our studies by treating $N$-benzylaniline (1a) and styrene (2a) with $5 \mathrm{~mol} \%$ iron as a catalyst. Initially, we tried to use a variety of iron catalysts to catalyse the cycloaddition of $N$-alkyl anilines and olefins under air (Table 1, entries 1-6). Trace amounts of the desired product (3a) were obtained with $\mathrm{FeCl}_{2}, \mathrm{Fe}(\mathrm{OTf})_{2}$, $\mathrm{Fe}_{2}\left(\mathrm{SO}_{4}\right)_{3}$ and $\mathrm{Fe}_{2} \mathrm{O}_{3}$, as detected by GC analysis, and a $28 \%$ or $33 \%$ yield was observed when $\mathrm{FeCl}_{3}$ or $\mathrm{Fe}(\mathrm{OTf})_{3}$ was used as a catalyst. To improve the reaction efficiency, different solvents

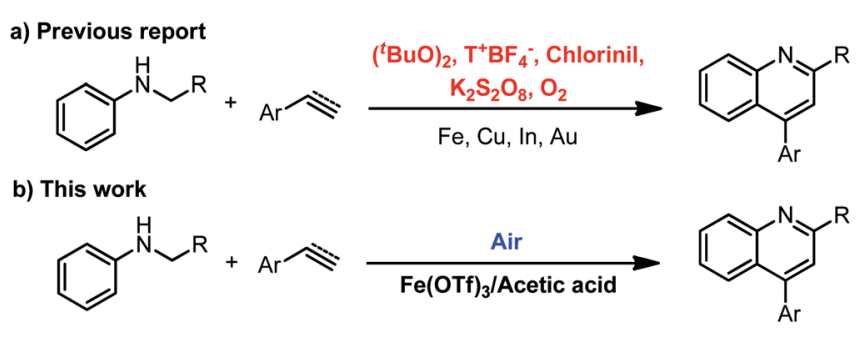

- Air as a terminal oxidant $\square$ Up to $96 \%$ yield $\square$ Gram Scale $\square$ Zebrafish experiment

Scheme 1 Different strategies for [ $4+2$ ] cycloaddition of $\mathrm{N}$-alkyl anilines and alkenes or alkynes by transition-metal catalysis. 
Table 1 Solvent effect and acid effect. $N$-benzylaniline $(0.2 \mathrm{mmol})$, styrene $(0.4 \mathrm{mmol}), \mathrm{Fe}(\mathrm{OTf})_{3}(10 \mu \mathrm{mol})$, acid $(0.3 \mathrm{mmol})$, toluene $(1.0 \mathrm{~mL})$, at $140{ }^{\circ} \mathrm{C}$ under air for $24 \mathrm{~h}$

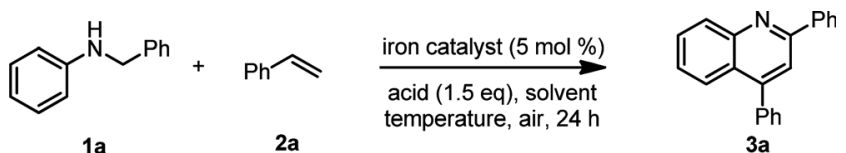

\begin{tabular}{|c|c|c|c|c|c|}
\hline Entry & Catalyst (5 mol\%) & Acid $(0.3 \mathrm{mmol})$ & Solvent & $T\left({ }^{\circ} \mathrm{C}\right)$ & Yield $^{a}(\%)$ \\
\hline 1 & $\mathrm{Fe}(\mathrm{OTf})_{2}$ & No & Toluene & 120 & Trace \\
\hline 2 & $\mathrm{FeCl}_{2}$ & No & Toluene & 120 & Trace \\
\hline 4 & $\mathrm{Fe}_{2} \mathrm{O}_{3}$ & No & Toluene & 120 & Trace \\
\hline 5 & $\mathrm{Fe}_{2}\left(\mathrm{SO}_{4}\right)_{3}$ & No & Toluene & 120 & Trace \\
\hline 6 & $\mathrm{Fe}(\mathrm{OTf})_{3}$ & No & Toluene & 120 & 33 \\
\hline 9 & $\mathrm{Fe}(\mathrm{OTf})_{3}$ & No & Dioxane & 120 & 0 \\
\hline 10 & $\mathrm{Fe}(\mathrm{OTf})_{3}$ & No & Nitrobenzene & 120 & 28 \\
\hline 11 & $\mathrm{Fe}(\mathrm{OTf})_{3}$ & No & Acetonitrile & 120 & 23 \\
\hline 12 & $\mathrm{Fe}(\mathrm{OTf})_{3}$ & No & Toluene & 150 & 42 \\
\hline 13 & $\mathrm{Fe}(\mathrm{OTf})_{3}$ & No & Toluene & 140 & 49 \\
\hline 14 & $\mathrm{Fe}(\mathrm{OTf})_{3}$ & No & Toluene & 100 & 16 \\
\hline 19 & $\mathrm{Fe}(\mathrm{OTf})_{3}$ & $\mathrm{TfOH}$ & Toluene & 140 & 0 \\
\hline 20 & $\mathrm{Fe}(\mathrm{OTf})_{3}$ & TFA & Toluene & 140 & 65 \\
\hline 21 & $\mathrm{Fe}(\mathrm{OTf})_{3}$ & PTSA & Toluene & 140 & 61 \\
\hline $22^{b}$ & $\mathrm{Fe}(\mathrm{OTf})_{3}$ & BNPA & Toluene & 140 & 57 \\
\hline 23 & $\mathrm{Fe}(\mathrm{OTf})_{3}$ & $\mathrm{HCOOH}$ & Toluene & 140 & 42 \\
\hline 24 & $\mathrm{Fe}(\mathrm{OTf})_{3}$ & $\mathrm{BzOH}$ & Toluene & 140 & 50 \\
\hline 25 & $\mathrm{Fe}(\mathrm{OTf})_{3}$ & AcOH & Toluene & 140 & 82 \\
\hline 26 & $\mathrm{Fe}(\mathrm{OTf})_{3}$ & $\mathrm{PhB}(\mathrm{OH})_{2}$ & Toluene & 140 & 35 \\
\hline 27 & $\mathrm{Fe}(\mathrm{OTf})_{3}$ & $\mathrm{~B}(\mathrm{OH})_{3}$ & Toluene & 140 & 15 \\
\hline 28 & $\mathrm{Fe}(\mathrm{OTf})_{3}$ & Phenol & Toluene & 140 & 54 \\
\hline $29^{c}$ & $\mathrm{Fe}(\mathrm{OTf})_{3}$ & AMSA & Toluene & 140 & 51 \\
\hline 30 & No & $\mathrm{AcOH}$ & Toluene & 140 & Trace \\
\hline
\end{tabular}

${ }^{a}$ Isolated yields. ${ }^{b} \mathrm{BNPA}=1,1^{\prime}$-binaphthyl-2,2'-diylhydrogen-phosphate. ${ }^{c}$ AMSA $=$ aminomethanesulfonic acid.

such as ethanol, mesitylene, 1,4-dioxane, nitrobenzene, acetonitrile and toluene were tested (Table 1, entries 6-11).

The optimal solvent for the reaction was toluene (Table 1, entry 6). Encouraged by this result, we examined a wide range of reaction temperatures (Table 1 , entries 12-17); the best yield was obtained at $140{ }^{\circ} \mathrm{C}$, but it did not meet our expectations.

We reasoned that an unreactive catalytic species, $\mathrm{FeL}_{2}$ (Scheme 2), could be formed in the reaction from the interaction of the imine intermediate and $\mathrm{FeL}_{3}$, which could not catalyse the conversion of imines to quinoline. Critically, the $\mathrm{FeL}_{2}$ species was difficult to oxidize to $\mathrm{FeL}_{3}$ under air conditions. Inspired by Birk's work, ${ }^{11}$ we envisaged that the addition of an acid may promote the oxidation of $\mathrm{Fe}(\mathrm{II})$ to $\mathrm{Fe}(\mathrm{III})$ under air. Based on this assumption, we proposed that $\mathrm{FeL}_{3}$ can undergo ligand exchange with $\mathrm{HL}^{\prime}$ to generate the active catalytic species $\mathrm{L}_{2} \mathrm{FeL}^{\prime}$. A subsequent oxidation reaction provided $\mathrm{LFeL}^{\prime}$, which was easier oxidize to $\mathrm{L}_{2} \mathrm{FeL}^{\prime}$ than $\mathrm{FeL}_{2}$ under air, enabling the next catalytic cycle.

Based on this hypothesis, we investigated some strong acids and moderate acids. Trifluoroacetic acid (TFA) was a cocatalyst that promoted the Fe-catalysed [4+2] cycloaddition of $\mathrm{N}$-alkyl anilines and alkenes to deliver 2,4-diphenylquinoline in 65\% yield (Table 1, entries 18-20). If 1,1'-binaphthyl-2,2'-diylhydrogen phosphate or $p$-toluenesulfonic acid (PTSA) were used instead of TFA, the yield was significantly reduced (Scheme 3, entries 21-22). For further improvement of the reaction, other

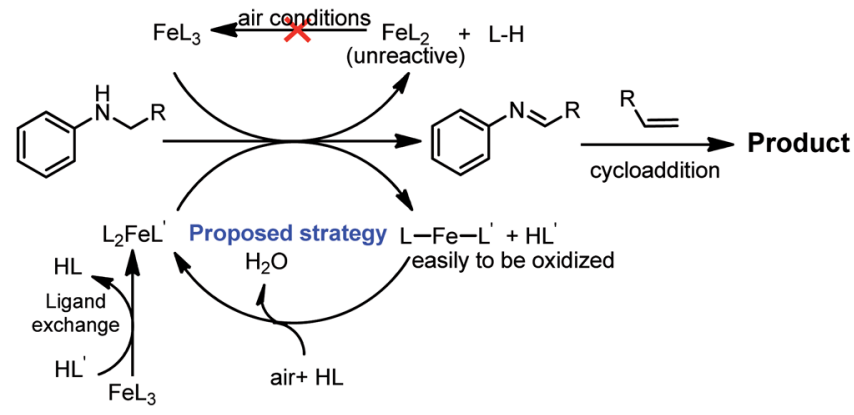

Scheme 2 Proposed strategy. 


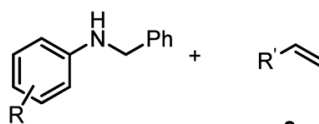

1<smiles>c1ccc(-c2cc(-c3ccccc3)c3ccccc3n2)cc1</smiles>

3a, $82 \%$<smiles>CCCCCOc1cc(-c2ccccc2)nc2ccccc12</smiles>

3e, $96 \%$<smiles>CCCCCc1cc(-c2ccccc2)nc2ccccc12</smiles>
$p-\mathrm{BrC}_{6} \mathrm{H}_{4}$

$3 \mathbf{i}, 71 \%$

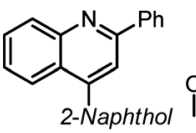

$3 \mathrm{~m}, 62 \%$

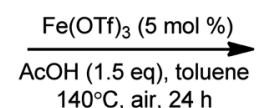

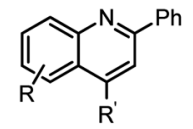<smiles>[GeH2]c1cc(-c2ccccc2)nc2ccccc12</smiles>

3b, $78 \%$<smiles>CCOc1cc(-c2ccccc2)c2ccccc2n1</smiles>

ff, $72 \%$<smiles>CCCOc1cc(Pc2ccccc2)nc2ccccc12</smiles>

$3 \mathrm{j}, 53 \%$

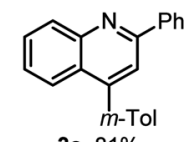

3c, $81 \%$<smiles>CCCCCC(=O)c1cc(-c2ccccc2)nc2ccccc12</smiles>

g, $69 \%$

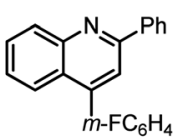
${ }_{m-\mathrm{FC}_{6}} \mathrm{H}_{4}$

3k, $59 \%$<smiles>Pc1cc([Te])c2ccccc2n1</smiles>

3d, $92 \%$<smiles>[18OH]c1cc(-c2ccccc2)nc2ccccc12</smiles>

$3 \mathrm{~h}, 78 \%$

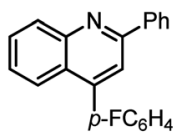

3I, $96 \%$

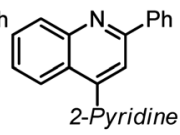

3p, 0\%

Scheme 3 Reaction conditions: substrate $1(0.2 \mathrm{mmol})$, aryl olefin $(0.4$ $\mathrm{mmol}), \mathrm{Fe}(\mathrm{OTf})_{3}(10 \mu \mathrm{mol}), \mathrm{AcOH}(0.3 \mathrm{mmol})$, toluene $(1.0 \mathrm{~mL})$, at $140{ }^{\circ} \mathrm{C}$ under air for $24 \mathrm{~h}$, and isolated yields of the products.

acid such as formic acid ( $\mathrm{HCOOH})$, benzoic acid (BzOH), acetic acid $(\mathrm{AcOH})$, phenylboronic acid, boric acid, phenol and carbamic acid were tested (Table 1, entries 23-29). The results showed that the addition of 1.5 equivalents of acetic acid was the best choice, furnishing the corresponding 2,4-diphenylquinoline in $82 \%$ yield (Table 1 , entry 25 ). Under the acidic conditions, a strong acid was completely inefficient (Table 1, entry 18), which suggested that the strength of the acid was critical to the reaction. Other acids did not give better results. Therefore, we performed the subsequent reactions between the $N$-alkyl anilines with alkenes or alkynes in the presence of $\mathrm{Fe}(\mathrm{OTf})_{3} / \mathrm{AcOH}$ at $140{ }^{\circ} \mathrm{C}$ under air conditions for $24 \mathrm{~h}$.

With the optimized reaction conditions in hand, a series of aryl ethylenes were investigated for extending the substrate scope (Scheme 3). This acid-promoted iron-catalysed dehydrogenative $[4+2]$ cycloaddition reaction displayed good functional group tolerance. Aryl ethylenes with electron-neutral or electrondonating groups on the aryl rings, such as alkyl, phenyl and naphthyl, all gave the corresponding 2,4-diarylquinoline with high selectivity in good yields. Aryls containing an electronwithdrawing group such as fluoro, chloro, bromo and ester were also tolerated and afforded the corresponding 2,4-diarylquinolines $\mathbf{3 e}-\mathbf{3 n}$ in moderate to good yields. Moreover, the reaction of $N$-benzylaniline $\mathbf{1 b}$ containing a substituent $(\mathrm{MeO})$ at the para-position of the aniline ring also produced the corresponding quinoline products 30 in $79 \%$ yield. These results indicated that different groups, such as methyl, phenyl, fluoro, chloro, bromo and methoxyl on benzene rings, were tolerated under the optimized reaction conditions. Notably, the retention of the $\mathrm{F}, \mathrm{Cl}$ and $\mathrm{Br}$ atoms in the structures of the products should make the products considerably useful in organic

transformations. Unfortunately, the current method could not be applied to olefins containing $\mathrm{N}$ heteroatoms, which was likely because of the strong coordination of $\mathrm{N}$ atoms with iron.

Next, the scope of arylacetylenes was also investigated, and the results are summarized in Scheme 4. Arylacetylenes could be used instead of arylethylenes for the synthesis of 2,4-diarylquinoline under the optimized reaction conditions. Similar good results were obtained, as shown in Scheme 4. Quinoline derivatives $\mathbf{3 a - 3} \mathbf{g}, \mathbf{3 i}, \mathbf{3 k}-\mathbf{3} \mathbf{m}$ and $\mathbf{3 o}$ were obtained in satisfactory to good yields $(63-96 \%)$.

To test the synthetic utility of the current method, a gram scale dehydrogenative [4+2] cycloaddition reaction of $N$-benzyl4-methoxyaniline with methyl-2-vinylbenzoate was conducted under the optimal conditions, providing the target $3 \mathrm{n}$ in $45 \%$ yield. To demonstrate the potential of our approach, we conducted molecular docking studies of human phenylethanolamine $N$-methyltransferase (hPNMT) and the quinoline derivatives. The studies were performed to help visualize possible interactions between hPNMT and the quinoline derivatives. The results showed that methyl-2-(6-methoxy-2phenylquinolin-4-yl)benzoate $3 \mathbf{n}$ may have $\pi-\pi$ interactions with ARG 90, and $\pi$-cation interactions with TYR 27 in hPNMT. Based on this docking result, $\mathbf{3 n}$ is highly likely to be a potent inhibitor of hPNMT. The results of the docked poses of hPNMT and $3 \mathbf{n}$ are shown in the ESI. $\dagger$ The zebrafish model has become an important vertebrate model for evaluating drug effects. ${ }^{12}$ To demonstrate the drug effect of $\mathbf{3 n}$ on the vascular system in the trunk of zebrafish embryos, we tested the activity of $\mathbf{3 n}$ in zebrafish. The test results showed treatment of zebrafish embryos with $1 \mu \mathrm{g} \mathrm{mL} \mathrm{m}^{-1} 3 \mathrm{n}$ resulted in morphological malformation, and treatment with $0.01-0.1 \mu \mathrm{g} \mathrm{mL} \mathrm{L}^{-1} 3 \mathrm{n}$ led to potent angiogenic defects (Scheme 5b). The results of this study will be of great significance for promoting drug research in cardiovascular and cerebrovascular diseases.

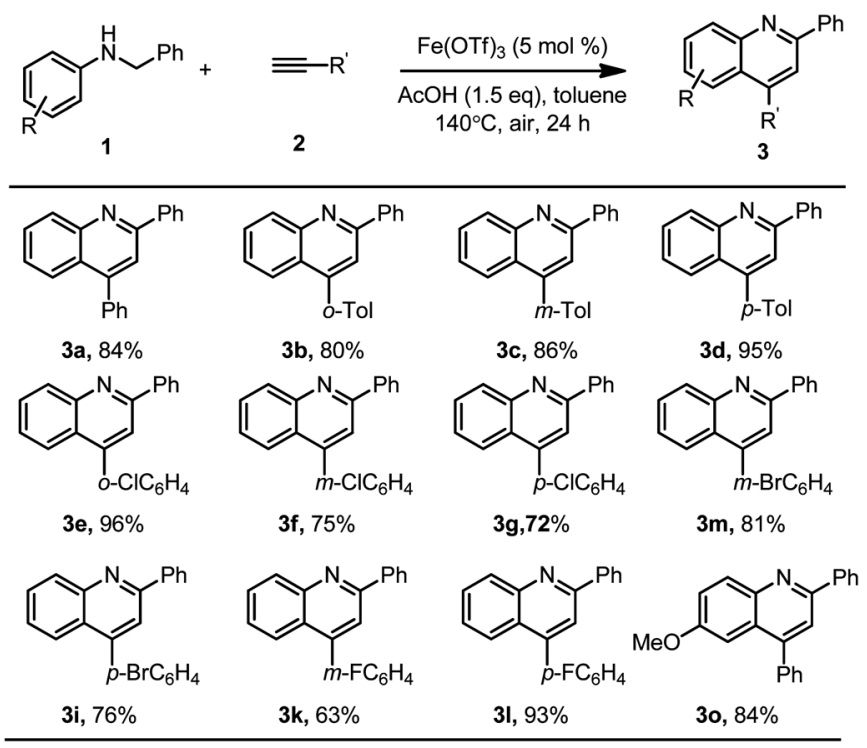

Scheme 4 Reaction conditions: substrate $1(0.2 \mathrm{mmol})$, aryl alkyne $(0.4 \mathrm{mmol}), \mathrm{Fe}(\mathrm{OTf})_{3}(10 \mu \mathrm{mol}), \mathrm{AcOH}(0.3 \mathrm{mmol})$, toluene $(1.0 \mathrm{~mL})$, at $140{ }^{\circ} \mathrm{C}$ under air for $24 \mathrm{~h}$, and isolated yields of the products. 
a) Gram-Scale Synthesis
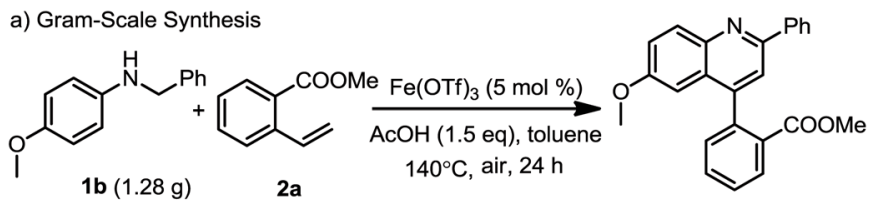

3n (45\%)

b) Drug Effect of 3n Treatment on Vascula
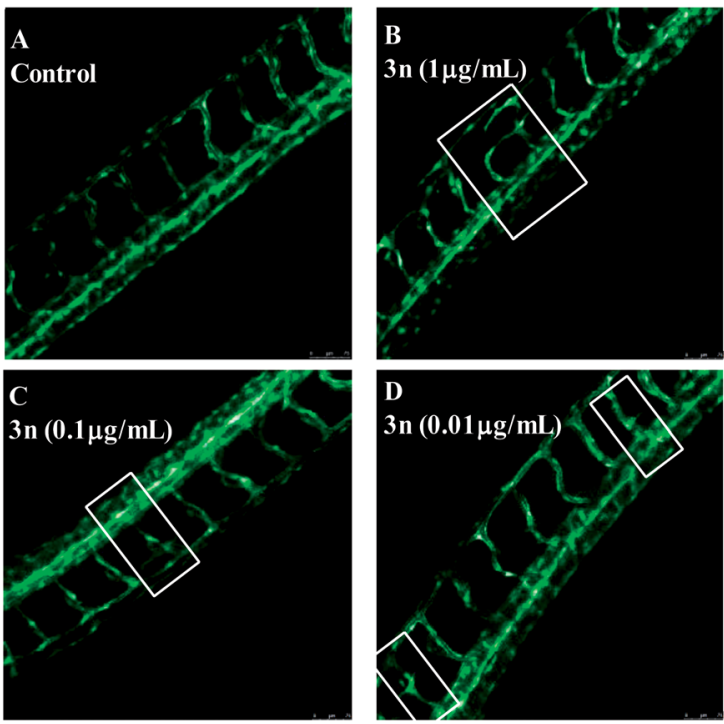

Scheme 5 Gram-scale synthesis and the drug effect of $3 n$ treatment on vascular in the trunk of $\mathrm{Tg}(\mathrm{kdrl}$ :EGFP) zebrafish embryos at $48 \mathrm{hpf}$ (A-D) control group and 1, 0.1, $0.01 \mu \mathrm{g} \mathrm{mL}-1$ n treated groups. Scale bar, $75 \mu \mathrm{m}$.

To gain a better understanding of the role of the acid, air and iron in the current cycloaddition reaction, additional experiments were conducted. First, control experiments showed that the absence of any of the three components, air, $\mathrm{AcOH}$ and $\mathrm{Fe}(\mathrm{OTf})_{3}$, significantly reduced the reaction yield, implying that each of the components was essential to this reaction. To clarify that the reaction was undergoing the production of an imine intermediate, we employed $N$-benzylideneaniline as a substrate to test if 2,4-diphenylquinoline could be obtained (Scheme 6). To our great surprise, 3a was obtained in $99 \%$ yield. The results showed that a cycloaddition reaction occurred after $N$-benzylaniline was oxidized to an imine. Based on these results, we proposed the following catalytic cycle: $\mathrm{FeL}_{3}$ first underwent ligand exchange with $\mathrm{AcOH}$ to generate an active catalytic species $\mathrm{L}_{2} \mathrm{FeOAc}$, leading to subsequent oxidative dehydrogenation to provide the imine intermediate and intermediate LFeOAc while releasing HL. The imine intermediate can then

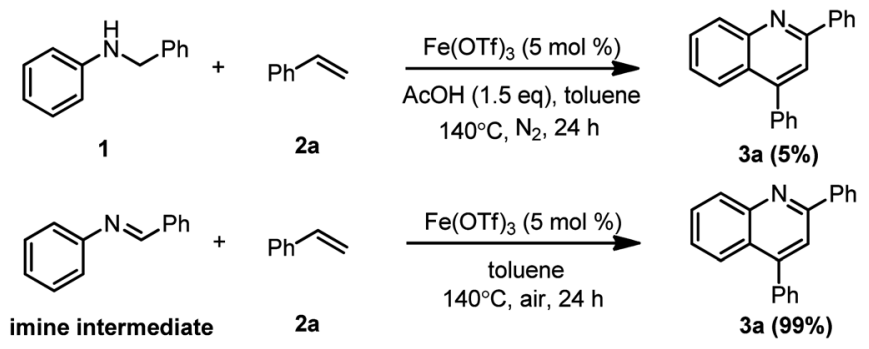

Scheme 6 Mechanistic experiments. undergo a $[4+2]$ cycloaddition with an alkyne or alkene, forming the desired 2,4-diarylquinoline or dihydroquinoline. A subsequent dehydrogenation reaction of dihydroquinoline provided the target product. The intermediate LFeOAc underwent an oxidation reaction in the presence of air to regenerate the catalytic species $\mathrm{L}_{2} \mathrm{FeOAc}$.

\section{Conclusions}

In summary, we successfully developed a highly efficient acidpromoted iron-catalysed dehydrogenative $[4+2]$ cycloaddition for the synthesis of quinoline under air conditions. The new method is compatible with alkenes and alkynes, and we performed molecular docking experiments with $3 \mathbf{n}$, which indicated that this compound might be an inhibitor of hPNMT. Moreover, we used the zebrafish model as an important way to demonstrate the drug effect of $\mathbf{3 n}$ treatment on the vascular system in the trunk of zebrafish embryos. The test results showed that $\mathbf{3 n}$ had a significant effect on angiogenesis. The results of this study will be of great significance for promoting drug research in cardiovascular and cerebrovascular diseases. Further investigation of cell experiments, animal experiments and other reaction types are under way in our laboratory.

\section{Ethics statement}

All animal procedures were performed in accordance with the Guidelines for Care and Use of Laboratory Animals of Nantong University and Experiments were approved by the Animal Ethics Committee of SYXK(SU) 2007-0021.

\section{Conflicts of interest}

There are no conflicts to declare.

\section{Acknowledgements}

We thank the National Natural Science Foundation of China (81430027 and 81671510), the National Basic Research Program (973 Program) (2014CB943100) for financial support. This work was also supported by the Fundamental Research Funds of Nantong University (03081105 and 03083002).

\section{Notes and references}

1 For selected reviews, see: (a) A. Danel, E. Gondek and I. Kityk, Opt. Mater., 2009, 32, 267; (b) H. Xu, R. Chen, Q. Sun, W. Lai, Q. Su, W. Huang and X. Liu, Chem. Soc. Rev., 2014, 43, 3259.

2 For selected reviews, see: (a) M. Orhan Puskullu, B. Tekiner and S. Suzen, Mini-Rev. Med. Chem., 2013, 13, 365; (b) K. Gopaul, S. A. Shintre and N. A. Koorbanally, Anti-Cancer Agents Med. Chem., 2015, 15, 631; (c) O. Afzal, S. Kumar, M. R. Haider, M. R. Ali, R. Kumar, M. Jaggi and S. Bawa, Eur. J. Med. Chem., 2015, 97, 871.

3 For selected reviews, see: (a) M. A. ElSohly and W. Gul, Recent Pat. Anti-Infect. Drug Discovery, 2007, 2, 222; (b) Y. Zhang, T. Han, Q. Ming, L. Wu, K. Rahman and L. Qin, Nat. Prod. 
Commun., 2012, 7, 963; (c) P.-Y. Chung, Z.-X. Bian, H.-Y. Pun, D. Chan, A. S.-C. Chan, C.-H. Chui, J. C.-O. Tang and K.-H. Lam, Future Med. Chem., 2015, 7, 947.

4 For related reviews, see: (a) J. Marco-Contelles, E. PérezMayoral, A. Samadi, M. d. C. Carreiras and E. Soriano, Chem. Rev., 2009, 109, 2652; (b) A. Majumder, R. Gupta and A. Jain, Green Chem. Lett. Rev., 2013, 6, 151; (c) S. M. Prajapati, K. D. Patel, R. H. Vekariya, S. N. Panchal and H. D. Patel, RSC Adv., 2014, 4, 24463; (d) R. I. Khusnutdinov, A. R. Bayguzina and U. M. Dzhemilev, J. Organomet. Chem., 2014, 768, 75; (e) B. Eftekhari-Sis and M. Zirak, Chem. Rev., 2015, 115, 151; (f) G. A. Ramann and B. J. Cowen, Molecules, 2016, 21, 986; (g) V. F. Batista, D. C. G. A. Pinto and A. M. S. Silva, ACS Sustainable Chem. Eng., 2016, 4, 4064; (h) G. Chelucci and A. Porcheddu, Chem. Rec., 2017, 17, 200.

5 (a) H. Richter and O. G. Mancheño, Org. Lett., 2011, 13, 6066; (b) P. Liu, Z. Wang, J. Lin and X. Hu, Eur. J. Org. Chem., 2012, 1583; (c) P. Liu, Y. Li, H. Wang, Z. Wang and X. Hu, Tetrahedron Lett., 2012, 53, 6654; (d) R. Rohlmann, T. Stopka, H. Richter and O. G. Mancheño, J. Org. Chem., 2013, 78, 6050.

6 (a) H. Huang, H. Jiang, K. Chen and H. Liu, J. Org. Chem., 2009, 74, 5476; (b) C. Huo, Y. Yuan, F. Chen and Y. Wang, Adv. Synth. Catal., 2015, 357, 3648; (c) X. Q. Yu, J. Wang, Z. W. Xu, Y. Yamamoto and M. Bao, Org. Lett., 2016, 18, 2491; (d) G. L. Liu, J. R. Qian, J. Hua, F. Cai, X. Li and L. Liu, Org. Biomol. Chem., 2016, 14, 1147.

7 (a) G. C. Senadi, W.-P. Hu, A. M. Gar-khedkar, S. S. K. Boominathan and J.-J. Wang, Chem. Commun.,
2015, 51, 13795; (b) N. Thirupathi, S. Puri, T. J. Reddy, B. Sridhar and M. S. Reddy, Adv. Synth. Catal., 2016, 358, 303. 8 (a) X. Yang, L. Li, Y. Li and Y. Zhang, J. Org. Chem., 2016, 81, 12433; (b) S. Parua, R. Sikari, S. Sinha, S. Das, G. Chakraborty and N. D. Paul, Org. Biomol. Chem., 2018, 16, 274; (c) S. Das, D. Maiti and S. D. Sarkar, J. Org. Chem., 2018, 83, 2309.

9 (a) X.-D. Jia, F.-F. Peng, C. Qing, C.-D. Huo and X.-C. Wang, Org. Lett., 2012, 14, 4030; (b) J. Liu, F. Liu, Y.-Z. Zhu, X.-G. Ma and X.-D. Jia, Org. Lett., 2015, 17, 1409; (c) X. Ma, Y. Zhu, S. Lü, L. Zhang, L. Luo and X. Jia, Tetrahedron Lett., 2016, 57, 1528; (d) M. Ni, Y. Zhang, T. Gong and B. Feng, Adv. Synth. Catal., 2017, 359, 824; (e) W. Ahmed, S. Zhang, X.-Q. Yu, Y. Yamamotoa and M. Bao, Green Chem., 2018, 20, 261.

10 (a) J. Kaschel, T. F. Schneider and D. B. Werz, Angew. Chem., Int. Ed., 2012, 51, 7085; (b) P. Dupau, M. L. Tran Do, S. Gaillard and J. L. Renaud, Angew. Chem., Int. Ed., 2014, 53, 13004; (c) F. Jia and Z. Li, Org. Chem. Front., 2014, 1, 194; (d) W. McNeill and T. Ritter, Acc. Chem. Res., 2015, 48, 2330; (e) R. B. Bedford, Acc. Chem. Res., 2015, 48, 1485; (f) C. Cassani, G. Bergonzini and C.-J. Wallentin, ACS Catal., 2016, 6, 1640; $(g)$ R. Shang, L. Ilies and E. Nakamura, Chem. Rev., 2017, 117, 9086.

11 R. Birk, H. Berke, G. Huttner and L. Zsolnaib, Chem. Ber., 1988, 121, 1557.

12 Y.-W. Shi, W. Yuan, X. Wang, J. Gong, S.-X. Zhu, L.-L. Chai, J.-L. Qi, Y.-Y. Qin, Y. Gao, Y.-L. Zhou, X.-L. Fan, C.-Y. Ji, J.-Y. Wu, Z.-W. Wang and D. Liu, Sci. Rep., 2016, 6, 30189. 